\title{
Chateaubriand's Atala and the Ready-Made Exotic
}

Rousseau used the exotic as a background, not to be questioned or fully noticed but to enhance the foreground. Bernardin de Saint-Pierre foregrounded the exotic, only to reabsorb it into the familiar. René de Chateaubriand, however, in his most popular fictions, Atala and René, gives the exotic the status of a subject, seeming to speak for its own self. His New World exoticism addresses its European public directly and appropriates the language of the exotic for its own discourse of the self; Chateaubriand's interest legitimates this appropriation, but in lending his voice to the exotic other, Chateaubriand necessarily subjects that address to his own inflections and turns exotic discourse into a discourse of the exotic.

Chateaubriand too compiles his exotic characters from existing texts, and his too is a discourse of power over the exotic, but in asserting this power, his fictions open the definition of the exotic to challenge. By building his work, as Gilbert Chinard has shown, on the exotic, Chateaubriand legitimates American material and makes it available for literature that is both serious and widely disseminated; he popularizes a version of the Americas which will at the same time encourage and constrain its domestic construction by the Americas. The thought and plot structures of his "American" works also establish models for a literature of cultural identity by foregrounding the definition and role of history, the inscription of the signs of the self on a formless other, and the opposition between incest and marriage plots. 
Chateaubriand's work is not much read these days, rejected in the light of our greater knowledge of, or different attitude toward, some of the subjects of his fictions. ${ }^{1}$ His work has been marginalized in the great rereading of French literature by psychoanalytic, structuralist, and deconstructionist critics. ${ }^{2}$ For decades now his books have encountered most of their public through truncated school editions. ${ }^{3}$ As texts for young people, they are invested less by the culturally determined signs of "great literature" than by a pedagogical intent more likely to invite rebellion and rejection than revaluation. Yet Chateaubriand's novels on exotic America are instances of the role played by European discourse in an American bid for voice and power, presiding like a mask of Janus over the autochthonization of European culture across the Atlantic.

Chateaubriand had in himself the cultural authority to shape the image of exotics-American and others-on both shores of the ocean. Part of that authority was biographical: a member of the aristocracy, he lost family and friends to the Terror, fought in the counterrevolutionary wars, and after hard years of exile in England, returned to parlay the huge success of Atala into public office under Napoleon's patronage. ${ }^{4}$

${ }^{1}$ Edward Said, for instance, is very annoyed by Chateaubriand's account of the "Orient" but acknowledges his importance in creating an image of the Near East for the European imagination. He also claims that Chateaubriand helped create the image of the romantic writer in particular, and of Middle Eastern civilization in general (Orientalism, pp. 172-75).

${ }^{2} \mathrm{He}$ is neither entirely ignored nor widely glossed. In the preface to Chateaubriand's Vie de Rancé, Roland Barthes discusses only the aging genius, omitting any reference to the young literary revolutionary ("La voyageuse de nuit"). Pierre Barbéris applies the newer critical tools to readings of René, Atala, Les Natchez (René de Chateaubriand; $A$ la recherche de l'écriture; and Chateaubriand). Chateaubriand, however, did not undergo the rescue operation performed, for instance, on Sade or Poe. A revision may now be under way, by an approach unlikely to have pleased him-feminist historicism, which sees his early works as part of a postrevolutionary construction (and repression) of femininity. See, for instance, Naomi Schor, Breaking the Chain: Women, Theory, and French Realist Fiction, and the articles by Schor, Gutwirth, Vallois, and Waller in Rebel Daughters. Waller distinguishes between Atala, which she sees as a cautionary characterization of the feminine, objectifying and distancing, and René, seen as inviting identification with the male. All see these texts-and Paul et Virginieonly as they function in postrevolutionary French culture.

${ }^{3}$ Richard Schwitzer, for instance, bemoans the "fate of Atala as a beginning French reading text" whose effects at that level can be "disastrous" (Chateaubriand, p. 90). Barbéris proposes that the "taming of the text" by "scholarization" and by cutting selected passages effectively counteracts the ideological danger of a "free and savage reading of the text" (René de Chateaubriand, pp. 15, 19-20); in this reading Chateaubriand is sufficiently subversive of the nineteenth century for acceptance in the canons of the late twentieth.

${ }^{4}$ Margaret Waller finds that the prescriptions and implications of René, Atala, and the volume from which they were excerpted, Le génie du christianisme, fit in precisely with 
He saw himself as a combination of Samuel de Champlain, Pierre Charlevoix, and (later) Napoleon, defending France and Christianity in exotic places. Combatant and exile, political maverick and literary innovator, he was both outsider and representative. ${ }^{5}$

Another part of his authority came from his works, which stand at the foundation of French romanticism; they make exoticism into the language of the romantic interest in rupture, desire, nature, and the self and provide continuity with the past greatness of French voyagers and travel writers, with Rousseau's meditations on the primitive and on the sources of political power, and with Bernardin de Saint-Pierre's literature of sensibility. ${ }^{6}$ His René replaces Werther's German crags with the forests of the New World, where it cries out the boundless longing and desire, the alienation and ennui the mal du siècle. For a time Chateaubriand was, as he says of Shakespeare, one who "invent[s] words and names that increase the general vocabulary of men," one whose "fictional characters become real" (Essai, p. 138). ${ }^{7}$ René and Atala escape the mediation of texts; they seem permeable and congruous with the extratextual. The combination of permeability of the text and cultural authority of the author allowed Chateaubriand's view of the Americas to impose itself on the New World and direct its literary experience.

Chateaubriand used previous discourse about the New World for a

Napoleon's plans to turn back the French Revolution (p. 158-59); Naomi Schor says that "Atala helped pave the way for the Napoleonic Code, first promulgated in 1804" ("Triste amérique," p. 144); there is a precise fit between Chateaubriand and his time. ${ }^{5}$ Chateaubriand's energetic life and multiple loves have inspired many biographies and his voluminous autobiographical writings are another endless source of information (or disinformation) about his life. I refer most often to George D. Painter, Chateaubriand: A Biography, which covers the period up to the publication of Atala and seems accurate on the facts.

${ }^{6}$ The introduction to one collection of excerpts from Chateaubriand's works begins by stating flatly that "Chateaubriand is more or less unanimously considered the founder of French romantic literature," as if it were merely repeating undisputed facts (Emile Faguet, Introduction to Chateaubriand, Atala, René, Le dernier Abencérage.) Intertextuality between Atala and Paul et Virginie is also taken for granted. See, for instance, the essays in Sara Melzer and Leslie Rabine's collection Rebel Daughters.

${ }^{7}$ This wording appears in the extended section on Shakespeare in the Essai sur la littérature anglaise (pp. 124-38) and is repeated in Mémoires d'outre tombe (1:504). One should also note Chateaubriand's contribution to the view of Shakespeare as a naive genius: "Fortunately, he knew almost nothing, and escaped, through his ignorance, some of the infections of his century" (Essai, p. 108). Chateaubriand's view of an innocent Shakespeare (such innocence more likely in a British than in a French genius, the British being less civilized than the French) mirrors his creation of Chactas as a savage of the Enlightenment, and shows his consistent attribution of value to what, in either system of significations, occupies the slot of the exotic. 
revolution in French literature and gave to the familiar the newly important prestige of the new. The overall authority of his writing legitimated the American elements it encodes and readied them in turn for use in an American discourse about the Americas. After the political rupture of independence, New World writers found in Chateaubriand autochthonous material as part of an authorizing European discourse that itself carried the marks of innovation and rupture with the past. Recent criticism has accused Chateaubriand of complicity with his times. I do not dispute it: it is not clear that anyone can escape such complicity. I contend, however, that Chateaubriand presented his works as innovative and, to an extent, oppositional and that they were so accepted by his readers. At the inception of French Romanticism, Chateaubriand's writing, according to Pierre Barbéris, "constitutes a rupture with received texts" (René de Chateaubriand, p. 11); as it became influential, however, and generated other texts, rupture itself became canonical and a mark of value, a condition for the acceptance of a text as culturally significant. ${ }^{8}$ But the rupture is tame, since Chateaubriand breaks with literary tradition in works that bid to restore the traditions broken by the Revolution and to garner their author a government appointment.

Still, by privileging exoticism and geographic displacement as formal signs of rupture, Chateaubriand set other worlds, more particularly the New World, at the center of contemporary European literary life and imagination. He made exoticism into the thematic basis for a literary, fictional discourse on otherness, alienation, and origins. This use of the exotic, at once serving rupture and preservation, encoded the reaction to-or recovery from - the French Revolution in a simultaneous absorption and rejection of the ideas considered responsible for its eruption and its violence. The choice of the New World as a worthy theme of European discourse encouraged the use of the exotic by American writers engaged in consolidating their own revolutions and formulating their own cultural worth and identity; there Chateaubriand gained authority by challenging literary traditions, for in legitimating a discourse of the other, he made such a discourse available to the other who breaks

${ }^{8}$ In Mémoires d'outre tombe Chateaubriand shows an ex post facto consciousness of his role in the development of the romantic sensibility: "In me there began, with the so-called romantic school, a revolution within French literature. . . . when I . . read fragments of the Natchez, of Atala, of René [to Fontanes], . . he could not associate these writings with the commonly accepted rules of criticism, but he felt that he was stepping into a new world, that he saw a new nature" (1:482). 
away from Europe to assert itself as a self. In effect, the significance of the Old World in the self-perception and self-definition of the New, the determination of the value of the non-European experience for either Europeans or Americans, the varying definitions of the boundaries between nature and culture, the role of Christianity in opposition to variously conceived and evaluated forms of paganism-all these are successfully and legibly formulated in Chateaubriand's works.

As has been seen in the works of Rousseau and Bernardin de SaintPierre, by the middle of the eighteenth century, the Americas were no longer identified simply by a catalog of parrots, cannibalism, and naked women, by justifications of conquest and conversion in a discourse of otherness and its domination; they had become available as proof, illustration, and ornamentation of European fictional, philosophical, and political argument. For Montaigne and Rousseau, notions of the Amerindians are integral to the analysis and criticism of European society, common and proven knowledge in need of no special documentation, true in general, if surprising in detail. Still exotic, exoticism had become familiar. Chateaubriand accelerated this familiarization while also reestranging it. His inscription of the New World follows the accounts of early explorers and missionaries and applies Rousseau's theoretical constructs in ways unexpected by the philosopher. ${ }^{9}$ It also expresses the newer European concepts of the primitive: the Mississippi Delta becomes a psychological refuge, a place for the expression of passions, rather than for political or philosophical freedom.

Knowledge about the New World had been available to Chateaubriand from his childhood: his father's fortune was based on New World trade (possibly in slaves), and his father's library held the writings of missionaries, traders, and explorers (Painter, p. 135). His friend old Chrétien de Malesherbes, a sponsor of Rousseau and Bernardin de Saint-Pierre and an enthusiast of the Americas, instructed him in his garden of acclimated tropical plants and encouraged him to cross the ocean to find the Northwest Passage. In Mémoires d'outre tombe, Chateaubriand claims to have taken quite seriously the idea of beoming an explorer: "If successful, I would have had the honor of imposing French names upon unknown regions, providing my country with a colony on the Pacific coast, taking the lucrative fur trade away from a rival power,

${ }^{9}$ One can imagine Rousseau's astonishment at seeing his ideas incorporated into the constitutions of new American nations, instead of guiding the polities of old Corsica and Poland, just as one can imagine Marx's at seeing a dictatorship of the proletariat installed where there was no history of industrialization like that of Western Europe. 
and opening a shorter way to the Indies, controlled by France" (1:287). Thus, when he sailed, Chateaubriand saw in the New World a haven from prerevolutionary France, an opportunity to reaffirm French imperial interests overseas, an occasion to verify Rousseau and Bernardin, recover the adventure of earlier times, assist in the spread of Christianity, and research a novel about the Natchez rebellion with which to make his name in French letters.

This explicit cross-referencing between life and letters is characteristic of Chateaubriand's method of mythmaking. He intended his explorations to be translated directly into glory for himself and for France as he dreamed it; his victories would be neither military nor commercial but spiritual and literary. ${ }^{10}$ Thus he read about the Natchez in Guillaume Raynal's book, then voyaged down the Ohio, and finally referred to John Bartram in order to complete the description of the trip and validate the insertion of his own fiction about the Natchez rebellion. The written and the lived validate each other. At the same time the sign of the exotic becomes almost autonomous; the exotic is lifted from its own context and decomposed into individual birds, plants, customs, tribes that may appear anywhere on a map of the New World, each sufficient to call up all the others.

But Chateaubriand himself does not propose this autonomy of the representative sign; he insists on its congruence with the experience of the signified and informs his readers that Atala is accurate, since it was written "under the huts of the savages" and since even American readers, who could have said "these are not our rivers, our mountains, our forests" (p. 22), accept its truth. ${ }^{11}$ His information as well as his protestations were in fact found convincing across the Atlantic, where Francis Parkman, for instance, classed him among historians (Lombard, "Chateaubriand's American Reception," p. 224). Yet the documentary strength of Chateaubriand's writings on the exotic arises less from their accuracy than from their congruence with what is already known. ${ }^{12}$

${ }^{10}$ The elaboration of the myth of Captain Cook, as documented by Gananath Obeyesekere in The Apotheosis of James Cook, provides an interesting contrast; the "practical" became enshrined, in the wake of English economic success; Chateaubriand's way faded before it, particularly in the consciousness of the English-speaking world. It is all the more interesting to find the traces of Chateaubriand's discursive strategies in the American literatures of nationality, boosted by an overt privileging of the "cultural" which sometimes hid and sometimes displaced the operations of the "practical."

${ }^{11}$ Unless otherwise noted, citations of Atala refer to the Weil edition.

${ }^{12}$ Not all reviewers thought his account accurate. An anonymous review article in the American Quarterly Review states that, though Chateaubriand "is evidently willing to 
Thus, although Chateaubriand's savage does not accord with Rousseau's theoretical construct of natural man, his Indian protagonists absorb the popular definitions of savage nobility and function as referents to non-European humanity. The reader of Chateaubriand's day found in Atala, René, and Les Natchez "real world" examples of Rousseau's theoretical natural men, even though Chateaubriand explicitly disavows that figure in his preface to Atala and claims to find raw nature ugly (p. 8). The demurral seems more than a little odd made by an author identified with a literature of exotic, primitive nature: in a characteristic double message, Chateaubriand indicates both the origin of his images and the transformation he operates on them; he has turned a sign of opposition to European civilization into one of integration between the exotic and its consumers and has reassured his readers that it is possible to enjoy otherness without engaging in it.

But Chateaubriand also normalizes the strangeness of the New World landscape by assimilating it to the well-defined cultural difference of a primitivism that stands at the origin of the contemporary and civilized: he presents primitives as ancestors and refers ancestry to classical antiquity. He knew the literature of paradise and golden ages lost and the more recent European recovery of its own primitives. He had translated Paradise Lost into French, and one of his friends had translated the Ossian poems. ${ }^{13}$ Asserting their continuity, he tried to be both modern man and bard: on the tedious Atlantic crossing, he welcomed the excitement of a serious storm by lashing himself to the mast and reciting Homer to the waves, and he whiled away a stop on the island of Saint Pierre by shouting lines from James Macpherson's Ossian epics at the sea from atop a lonely rock.

Chateaubriand's travels in America exist in the flattering twilight between asserted fact and acknowledged fiction, presented in a discursive

have it thought, that he had lived long, and traveled much in our wilderness, and among our Indians . . . this cannot be. His descriptions of scenery in Atala and the Natchez, are thoroughly false." Still, the critic praises Atala because "the imagery, the feelings, the language, are borrowed from a state of nature" and because it "takes human nature ... o one step higher in its moral history [than Paul et Virginie had], and precisely at that point, where the first blending of the influences of society with savage life produces that development of the feelings and passions, which is, perhaps, the most favorable for poetry and fiction." At the end the article invokes classical Greek literature as a yardstick for this writing of the New World, inasmuch as it too was in that liminal state "which gave us the Iliad" ("Works of Chateaubriand," pp. 460,471$)$.

${ }^{13}$ In the Furnes edition the Essai sur la litterrature anglaise is followed by the original English and Chateaubriand's prose translation of Milton's epic. 
mode in which the ideological component promises to reveal the truth and in which the boundaries between the read and the lived are blurred. ${ }^{14}$ Though he tells the trip at least twice, in Voyage en Amérique and again in Mémoires d'outre tombe, his precise itinerary is still a matter of conjecture and the accuracy of his reporting, a cause of controversy. We know that he avoided the cities, centers of the administrative and intellectual life of the new republic he professed to admire. ${ }^{15} \mathrm{He}$ did not, when he had a chance, examine what its vaunted civic virtue had achieved; instead, he set off with a guide and two bearskins in the direction of Niagara Falls and then with traders down the Ohio. The rest is vague but exotic; eventually he headed back to the East Coast. ${ }^{16}$

${ }^{14}$ Many studies document Chateaubriand's borrowings; Joseph Bédier's, one of the earliest, concludes that Chateaubriand never set foot in the region where he places the action of Atala (Etudes critiques, pp. 125-294). Gilbert Chinard finds the sources of Chateaubriand's America in his early readings of Raynal and the missionaries he wanted to imitate, and also in the fiction of exoticism popular at the time, particularly Paul et Virginie, credited with introducing into French literature a "modern form of exoticism" to which Atala became one of the most notable contributions (L'exoticisme américain, p. vi). Armand Weil identifies various passages borrowed from travel literature, including works by Gilbert Imley, Jonathan Carver, Pierre Charlevoix, and John Bartram, the last probably furnishing the name of the Indian hero of Atala (Introduction to Chateaubriand, Atala, pp. lxix-lxxxiv). Christian Bazin finds the written antecedents of Chateaubriand's America in travel literature; in Marmontel's Incas, Voltaire's Zaire, Bernardin's Paul et Virginie; and in works now completely forgotten, such as Odéralis: Histoire américaine, contenent une peinture fidelle des habitans de l'interieur de l'Amérique, an anonymous romance published in Paris in 1795, or Nicolas de la Dixmérie, Azakia: Anecdotes huronnes (1765) (Chateaubriand en Amérique, pp. 186-87). Chateaubriand did not invent his materials or even pioneer the use of his subjects; he restructured them, making them newly readable.

${ }^{15}$ In Mémoires d'outre tombe Chateaubriand is relatively kind to the cities he visited, though significantly he complains not only about materialism and inequality but also about the lack of "monuments" in Philadelphia (1:278). As Michel Riffaterre argues in "Chateaubriand et le monument imaginaire," Chateaubriand associates "monuments" with history and the legitimation of a polity by its connection with the recorded past; his criticism of the new cities is therefore not just aesthetic but implies a judgment of value and a pronouncement on the legitimacy of the civilization they represent.

${ }^{16}$ In many instances Chateaubriand was more interested in the shape of his story than in the accuracy of its details; so his precise itinerary in the United States has been a matter of controversy. Appendix 14 to Mémoires d'outre tombe traces the polemic (1:593-98), and provides one map (p. 597) of the itinerary according to Bédier (p. 145), who has Chateaubriand reaching the towns of Natchez, formerly French, and Cuscowilla in Florida; a second, currently more widely accepted route takes the Ohio River to the Mississippi and returns by way of, say, Louisville. Painter concludes that, though most probably Chateaubriand went to Niagara Falls, the southern portion of his trip is less certain, its descriptions showing many traces of previous writings about the regions he claimed to have visited (pp. 200-214). Throwing up his hands in frustration, Painter summarizes: "His commentators agree that [after leaving Niag- 
His itinerary and its vagueness indicate that even if the voyage to America was undertaken to validate the literary through the factual, its most important acts were performed for their symbolic load. With his attempted visit to George Washington, to whom he had brought a letter of introduction, Chateaubriand honored, somewhat perfunctorily, the American embodiment of Roman civic virtue and the promise of a return on the American continent to the values of the European past. ${ }^{17}$ His pilgrimage to Niagara honored the untrammeled power of nature. ${ }^{18}$ The trip down the Ohio honored, by emulation, the early (French) explorers of the continent. His second recounting of the voyage (Mémoires d'outre tombe rearranges and summarizes what had been told in Voyage en Amérique) incorporates not only the political, mystical, and historicogeographical facets of his experiences, but also samples of other travel writings: the famous incident in which he plays with the "two Floridians," Indian maidens who appear to him while he is resting on a river island, seems to have been inspired by Bartram (Painter, p. 206); the amusing episode of the little French dancing master fiddling in the forest and teaching a minuet to the savages has a counterpart in the travel account R. G. McWilliams identifies as the Penicault Narrative. ${ }^{19}$

ara] he cannot have gone where he says he went, even though they are unable to decide where he does say he went, or to find evidence that he went anywhere else." Later he declares: "It must be admitted that at this point his itinerary becomes vague, inexplicit, dreamlike, as he turns from the truth of factual realism to the truth of poetic beauty" (p. 191).

${ }^{17}$ Chateaubriand's visit to Washington, which he describes in Mémoires d'outre tombe (1:279), comparing the American president to Cincinnatus, has also been a matter of dispute. The actual letter of introduction Chateaubriand took to Washington, from the marquis de la Rouërie, spent a long time buried in the collections of the NewYork Historical Society before it was found by E. K. Armstrong and published in PMLA (see Mémoires, app. 14, 1:607). From the existence of that letter Painter deduces that Washington did receive Chateaubriand, etiquette pertaining to letters of introduction making it imperative that the carrier should call and be received (p. 177). Chateaubriand makes a great effort to discern Roman traits in the New World city of Philadelphia and its inhabitants (Mémoires, 1:278-80).

${ }^{18}$ Niagara was a necessary point of pilgrimage in visits to North America, and as Peter Conrad shows in the introductory chapter of Imagining America, it is a kind of Rorschach blot where tourists see their own characters, their own expectations or prejudices about the land and the nation they had come to visit.

${ }^{19}$ Fleur de Lys and Calumet, Richebourg Gaillard McWilliams's edition and translation of the Penicault Narrative, includes a spirited account of how French visitors to an Indian village near Mobile played their fiddles, moving the Indians to dance, and then demonstrated a minuet to them (pp. 106-7). The coincidence does not prove that Chateaubriand knew that particular story, but Charlevoix was one of the many writers on French America who used the Penicault manuscript as source material (see McWilliams, Introduction), and Chateaubriand had read Charlevoix. 
In this writing and rewriting of America, Chateaubriand further transforms the discourse of American exoticism and reincorporates it in the imagination and literary language of Europe. The intertextual impulse of his work is strong enough that, although he rejects Rousseau's concept of the natural man-inasmuch as "the natural man of Du contrat social was unqualified to sign the contract which Rousseau imputes to him" given the limits of his experience (Shackleton, "Chateaubriand and the Eighteenth Century," p. 16)—Chateaubriand presents his younger self as emotionally drawn to "primitives," excited by sharing night camp with a family of Indians and exchanging greetings with a true representative of natural man or disappointed and "cruelly humiliated," in his quality as a "disciple of Rousseau," at the sight of the dancing master's hopping pupils (Mémoires, pp. 301-3, 291). Chateaubriand fleshes out the philosopher's theoretical construct, validating the original inhabitants of the Americas by the theory rather than testing the theory against them. When he leaves unsatisfactory Philadelphia to sleep on his bearskins under the stars, when he restores the Ohio to an assumedly original solitude that eliminates the trade that allowed him to sail it, Chateaubriand abstracts the republic he holds up for admiration from the historical circumstances of its existence and charges it with representing in fact what Homer or Macpherson can offer only as myth or fiction. As Barbéris contends, even in writing the epic of the Natchez, he fixes the event in a half-mythic past, a recovered European prehistory reassuringly both familiar and remote. ${ }^{20}$

Filtering his experience of America through his reading, his memory, and his writing, Chateaubriand forged the image that for at least half a century shaped the way in which the New World was spoken and thought of in the general European imagination: its place in the opposition between nature and culture, the sensual freedom marking both its attractiveness and its distance from true civilization, the relation between its own and European history. To the extent that autochthonous discourse on the Americas came to participate in the ideological and linguistic universe of the metropoles, moreover, directed at both sides of the Atlantic-the one guaranteeing its authenticity and the other its readability-Chateaubriand's Americas come to ground an American discourse of America, with its own canon of acceptable forms. His memoirs and his fictions made the exotic comfortingly familiar, ready to be

${ }^{20}$ According to Barbéris (Chateaubriand: Une réaction, pp. 63-64), although Natchez mentions French political developments of 1715-1725, its comments can also be read as relevant to the events of 1789-1792. 
appropriated with wonder and tranquillity, as a novelty that does not challenge an accustomed distribution of power. His America was authorized by an extensive literature of exploration and empirically verified in his own voyage across the ocean; it was further authorized by his use of the popularized version of Rousseau's vocabulary as well as his rejection of Rousseau's controversial theories; finally, it was authorized by his membership in the intellectual, social, and political elite of his time. Even more than his image of the Americas, it is this authority that the national literatures of the Americas would strive to appropriate.

Chateaubriand's best-known work and greatest success was Atala, published in 1801 as an extract from a promised larger epic, Les Natchez, and later incorporated in Le génie du christianisme. It was from the beginning a blockbuster, spawning, like Paul et Virginie, a lively retail trade in prints, lamp shades, and coffee cups, which commercialized and popularized exoticism. The novel was immediately translated into a number of languages, reprinted abroad (there are American editions as early as 1801), imitated and adapted for the theater; it is still taught in schools. ${ }^{21}$

It tells the story of the Indian maiden Atala and her lover Chactas, whose two tribes are enemies and whose love is doomed by the disorder of savage lives as well as by the imposition of Christian values; by the impulse toward an ambiguously valued fusion of American and European blood and civilization, as well as by a fatal cultural diffusion and displacement. Even more clearly than Paul et Virginie, Atala develops the thematic clusters of a literature about otherness, the commonplace signs of unequal power relations between cultures: sexual contact, history, the complex concept of nature, and writing.

As in Paul et Virginie, the marriage plot in Atala fictionalizes contact between members of different cultures and the possibility of establishing a new, synthetic unit in terms that mimic an extreme form of exogamy; it then shadows it with a test of the prohibition against endogamy by adapting the common eighteenth-century interest in sibling incest and opposing the fear of the other with the desire for and the taboo against the same. Atala also raises the problem of history in the New World, making its absence, as usual, redeem European misdeeds and ensure European superiority. In a still plausible metaphor, it connects cultural with individual development: without history, Americans-

${ }^{21}$ Weil devotes a long section of his introduction to an account of the multiple direct progeny of Atala (Atala, pp. xxxi-lxi). For American adaptations and imitations, see Lombard, "Chateaubriand's American Reception," pp. 222-24. 
Amerindians or colonists-are like children. The introduction of a school edition of Atala explains, with the certainty of ideological assertions, that Chateaubriand is an accurate reporter of the condition of New World populations, "whose semi-childish mentality . . . is in close correspondence with historical truth." 22 The assertion justifies continuing European tutelage, but the text can also, with the common perverseness of texts, invite an American cultural work that reads Atala as a record of European desire to flee from history into the American wilderness, valued because it escapes that tutelage.

Finally, Atala contains a startling codification of the imposition of signs on that same wilderness whose redemptive value depends on freedom from imposed significations. Its landscape, at first sight, occupies a "natural," neutral, and unmarked slot in opposition to a European culture in search of its complement. This neutral and unmarked landscape, however, is also incommunicable until Europe begins to map, that is, to write, the wilderness. The desire for nature as wilderness is revealed as the desire for the void, for nature as absence, which however must become a plenitude if it is to mark the boundaries of Europeanness. Atala and René oscillate paradigmatically between the oppositions of nature and culture, myth and history, absence and presence.

Atala approaches the questions of marriage, history, writing in wellestablished ways; insofar as it shapes discourse, its power derives also from its place in the literary and other politics of its time and place of origin. It is not only an exotic love story but also part of the Génie $d u$ christianisme, Chateaubriand's proposed contribution to restoring the values of order and Christianity battered by Enlightenment philosophers and revolutionary mobs. Resolutely straddling apologetics and entertainment, Atala spices the uplifting with the sensational and, like lobster bisque on a day of abstinence, makes religious duty into sensual pleasure. It presents itself to its wide and varied public as a palatable defense of a civilization indisputably valuable in itself, its boundaries

\footnotetext{
${ }^{22}$ Raymond Bernex, Introduction to Atala, p. 11. The introduction discusses Chateaubriand's itinerary and after reviewing the literature, comes to definite conclusions (he did not go down the Mississippi; he did go to Niagara Falls), but it also concludes that the precise facts are not that important. "What really matters is their incantation" (quoted from V. - L. Tapie, Chateaubriand par lui-même, 34), contributing to the canonical mix of certainty and inaccuracy which characterizes the purely ideological image of the other. This edition also reprints illustrations from various editions of Atala, as well as some of the better-known portraits of Chateaubriand, documenting the popular iconography of the novel and its author.
} 
clearly marked by the surrounding barbarism found both in the paganism of the untouched New World and in the blasphemy of a desacralized Old World.

The story of Atala reaches the reader at the end of a chain of narration that transforms an oral account into written history. The narrator arrests the transmission of tales through generations of non-European protagonists now near extinction and translates it into a book for a growing and increasingly literary public, which still remembers with residual familiarity the credibility and verisimilitude of the spoken word. Atala thus operates a transition between an ahistorical America and a Europe of the written word; the scribe in the text witnesses the destruction of the narrating voice and preserves its narrative of the destructive encounter between the written and the oral, the historical and the mythic.

But reversing the ascription of power to Europe and decay to conquered America, the exchange of life stories which composes the tale is also designed to cure the disease of civilization from which the young Frenchman René suffers by integrating him into an Indian tribe. The old Indian Chactas tells René of his life and tragic love. Chateaubriand, in another reversal of values, establishes Chactas's authority by describing him as blind like Homer and Ossian, guided by a young girl as Oedipus was guided by Antigone; he is also partly civilized, having been transported to France as a galley slave; there, he had enjoyed the privileges of an exotic specimen-had met with Louis XIV, heard Jacques Bossuet, spoken with Voltaire, attended performances of tragedies by Racine, and befriended Fénélon. ${ }^{23}$ Chactas's story is thus placed in a precise, Western (in this case, French: "Western," like "European," is always metonymic) historical context that counterbalances the American ahistoricity of his origin and the narrative chain that acquaints us with him. He had seen France at one of the recognized high points of its civilization, and the respect accorded him by great Frenchmen makes him respectable. His personal history introduces into the text a brilliant European historical past against which to set the value of the American continuous present, and his success at court allows Chateaubriand to sidestep two ideologically troubling matters: the influence of the American Revolution on French history and the moral standing of a European

${ }^{23}$ Weil suggests that the outline of Chactas's history is derived from the story of a Hottentot who was raised in Europe but rejoined his people on the first opportunity, told in a note to Rousseau's Discours sur l'origine et les fondements de l'inégalité (Introduction to Atala, p. lxxii). 
society whose civilizing contact with the hero is made by means of his enslavement.

If pursued, the question of Chactas's enslavement-like that of the slaves on the island and Virginie's Parisian education in Paul et Virginie-would threaten the allocation of value between his world and that of the Europeans who displace him, between the powerless, desirable exotic and the empowered civilizer. Chateaubriand's strategy for neutralizing such concrete questions of value is to make Chactas successful in both worlds and to particularize the problem raised while generalizing proposed solutions. Chactas's enslavement appears simply as a surmounted obstacle in his individual biography, but his privileged position in the French court and intellectual world holds out a promise to the exotic in general. His experiences allow the old Indian to walk, as we are told, "on the line . . between society and nature" (Atala, p. 9), opening the two sides to each other. Chactas's first words to René and to the reader are "I see in you the civilized man who has made himself into a savage, you see in me the savage man whom the Great Spirit . . . has desired to civilize." But the sequel to Chactas's statement reintroduces the matter of values into the encounter between Europe and America, placing on the protagonists the burden of an unresolvable ethical problem when Chactas asks: "Who of us two has gained or lost more with this change in position?" (p. 35). This question of valuation undermines the strict position of mediation which the first utterance seems to establish, but it opens the space for Chateaubriand's discourse: it is the space in which arise the strategies for self-valuation in the literatures of the New World, the space of choice, where it is implicitly asserted that civilization and barbarism are not givens but subject to change and to the will. His own discourse becomes possible in the apparent decision between them which inscribes civilization on savagery.

This is Chactas's story. As a young boy, he is orphaned in a war between his own and an enemy tribe: Indian politics occasions the first European interference in Chactas's life and allows Chateaubriand to transpose the customary justification for European interference in the affairs of native populations from the political and ideological to the biographical. ${ }^{24}$ The noble Spaniard Lopez rescues Chactas from his enemies, teaches him the language, customs, and religion of the whites,

${ }^{24}$ Hulme discusses early colonial European politics of interventions, which justified colonists' suppression of both sides by recasting local rivalries in moral terms (Colonial Encounters, pp. 47, 53, 76-77). 
and lets him return to the wilderness when, "after having spent thirty moons at St. Augustine, [he] was seized with disgust for the life of the cities" (p. 36). Like his listener René, Chactas has fled civilization in disgust. As soon, however, as the de-savaged Chactas is released into the forest, he is captured by the tribe that had orphaned him, tied up, and judged worthy of sacrifice; he is shown as incompetent in the forest but possessed of a generalized Indian nobility. For the reader, inasmuch as his is the unquestioned nobility of nature and his capture is the act of men-in-nature, the differences between them are neutralized, submerging both tribes in one embracing otherness.

That night there comes to the prisoner the most lovely maiden of the enemy tribe, dressed in a long, flowing white gown, and wearing a small cross around her neck. Atala looks like an Indian Virginie, but her stated function as a "bride of the last night" contradicts and completes her presentation as the prototypical virgin of romantic fiction: the symbol around her neck controls the titillating signs of sensuality with which her (exotic) role invests her, but it also draws the acceptable boundaries of her sensuality by subjecting it to European rules and values. Thus the love between Chactas and Atala is organized as an exotic variation on traditional European marriage plots that consider the possibility of unions between protagonists of different social class, birth, or fortune and solve the problem of difference by invoking the leveling potential of personal merit, chance, or an essential similarity hidden through adverse circumstances. Nevertheless, the cross does not erase the exotic, which opens the plot to additional exploration of the possible relations between different cultures. Once again, the central topos of the encounter between Old and New Worlds is encoded in terms of endogamy and exogamy, but though he goes farther than Bernardin, Chateaubriand too avoids an actual limit case, for the Indianness and the Europeanness of the protagonists are incomplete. Chactas's history and Atala's cross invade an anthropologically justified account of "savage" customs; they reveal the extent to which the documentary claims of the novel are subject to European use. This invasion of the native context also prefigures the development of the lovers' relationship, which becomes problematic only through interference from explicit European, Christian rules that forbid its fulfillment without marriage or from implicit rules that ban marriage between members of different groups. It is important in this sense, as will be shown later, that the education of Chactas by Lopez acquires a quasi-genetic character, touching extreme exogamy with incest, establishing an equivalence be- 
tween physical and institutional channels for the transmission of cultures, and lending to the taboo separating culture from culture the legitimacy of separating culture from nature. Finally, it is precisely the inconsistency of the lovers' definition as either savage or civilized, as separated either by excessive closeness or excessive distance, that makes Atala into a seminal text for encoding both the characteristic and the differentiating traits of national identity in the early literature of nationality.

Chactas and Atala fall in love immediately; she offers to free him and, upon his insistence, to flee with him. They escape through a nowbenign forest of melodiously named trees, of water buffaloes rising like river gods from streams where crocodiles bellow, of birds and flowers glittering among the foliage in encyclopedic variety. Like a sampler, their paradisiacal wilderness juxtaposes signs denoting a generalized American state of nature in opposition to societies where the cross, the dress, or-Chactas's Indian captors classified for the nonce as an oppressive society-the sacrificial stake constrain individual action and thwart desire.

That juxtaposition of signs constructs the exotic within an unequal power relation: the more powerful language creates the "exotic" as it generalizes differentiating traits, imposes its own familiar values on them, and finally, as a condition of acceptance and intelligibility, negates otherness. When Chateaubriand places a semitropical forest on one side of the Mississippi and a prairie on the other, when his crocodiles produce amber under tamarinds, when he arranges nature in spectacle, rather than with the mimetic accuracy explicitly claimed for the descriptive, "factual" presentation of his material (Bart, "Descriptions of Nature," pp. 83-93, esp. 84), he is exercising the privilege of an external, powerful discourse to make the other into the typical, ready for easy consumption. Differentiating signs become interchangeable; the prairie indicates otherness and Americanness as easily as the Spanish moss or the doeskin-clad Indian. The presence of a number of such signs simply reinforces the common reference without introducing either differentiation or complexity. But this exotic picturesque is simply a delicate, inventive sauce. The meat is in the characterization of Atala, where juxtaposition encodes otherness in a culturally more powerful process of normalization: an Indian maiden, she wears the garb of European iconographic representations of the not-yet-sensual and not-yetassigned feminine, underscored by an iconographic mark of spirituality, but she appears in the story in the role of a sexual partner assigned by 
alien custom. As the rules governing sexual behavior are most often explained and understood in terms of what is "natural" (or, conversely, "perverse"), differences in their operation are simple, intuitive markers of otherness. In the figure of Atala, Chateaubriand formulates the definition of otherness in terms of the natural and the sexual but does not make explicit the lines of opposition within these fields. The resulting ambiguity appears even in the description of Atala's expression, a composite of the accepted and the devalued, though desired feminine: "On her face there was something virtuous and passionate . . . an extreme sensibility linked to a deep melancholy" (p. 40). The cross she wears indicates the other's acceptance of identity and value from an external power and presupposes an active acquiescence from a recipient ready to erase part of his or her difference and identity. The sensibility in Atala's expression and her flowing white garments (p. 60), on the other hand, mark the other as essentially familiar, reducing the traits of its difference. Thus otherness is assimilated, and empathy shades into the exercise of power. Any residue is then defined as a deficiency, always imperfectly remedied: as we shall see, Atala makes an imperfect Christian.

The flight of Atala and Chactas continues to encode the difficulty of representing true otherness. The forest seems to replace the constrictive-or fatal-determinations of social groups, Spanish and Indian, with the freedom of nature, but the freedom is qualified by its danger to a "natural" distribution of power. Chactas, a man brought up among Europeans, cannot survive in pure American nature and must rely on Atala, who teaches him to feed, clothe, and find himself in the wilderness. Atala could free Chactas because she was the daughter of the chief; she can teach love and living in nature because she is natural, a daughter of the forest. These attributes elevate her above Chactas, imprisoned, incompetent, contaminated with Europeanness. But the promise that her teaching and her help offer Chactas and, by extension, René, refugees from civilization, dissipates under the constraints Chateaubriand imposes on her.

The lovers' flight through the forest also traces the disturbance of the boundary between the natural and the social occasioned by the encounter with the other. In direct contact with nature unmediated by social organization, the lovers necessarily confront the basic social question of sanctioned behavior toward each other, posed in its most striking aspect, sexuality. Any society encodes the limits on its expression in a complex system of rules, from the fundamental taboo against incest to 
the positive regulations organizing the choice of a mate. Like Bernardin de Saint-Pierre and the first Europeans, who, confronted with their first naked Amerindians, decided that such marked deviation from a European dress code signified complete sexual availability and therefore the absence of any codes of conduct, Chateaubriand must consider the consequence of life "in nature" on a regulated sexuality seen as the mark of "culture." 25

In the forest, away from restraining social codes, Chateaubriand's young heroes face the possibility of a moral renewal beyond the corrupting forces of civilization. But their freedom makes him nervous, and after a few pages Chateaubriand finds it necessary to reinstitute restraints to the free operation of their passions. His unease is not only psychological but also ideological. Inasmuch as the novel intends to reestablish Christian morality in a society that had experimented with its removal, these rules of sexual conduct must appear "natural," the inescapable moral basis of any viable codification of behavior, operating in the heart of the forest and of the individual, governing the actions of even those who live beyond the boundaries of the encoding culture. Loving and passionate, fleeing from socially prescribed death, free in the forest where only their own natural feeling for propriety guides their actions, Atala and Chactas embrace. What limits, if any, can individual choice impose on this embrace? To what extent does nature, which has made them virtuous, regulate their passions, which, though natural, cannot, if morality is also to be natural, be left to reign unchecked?

Chateaubriand reintroduces the system of checks that must finally characterize even an alternative society in the passage where the growing physical attraction between the two lovers culminates:

"From there on the struggles of Atala became useless; in vain did I feel her raise a hand to her bosom . . . ; already did I hold her tightly in my arms, and was drunk with her breath, having sipped all of love's magic from her lips. With my eyes turned toward heaven, I held my spouse in my arms by the flashing lights of the storm, and in the presence of the Eternal One. It was a wedding feast worthy of our misfortunes and of the greatness of our love: sublime forest that made your domes of verdure and lianas billow in the wind like the curtains

${ }^{25}$ Todorov notes the progression from observations on dress to conclusions about cultural states: "Physically naked, Indians are also, in Columbus's eyes, devoid of any cultural characteristics [such as] mores, rites, religion" (Conquête, p. 41). 
of our bed, flaming pines that became the torches for our hymeneum, raging flood, bellowing mountains, awesome and sublime nature, . . . could you but hide for one moment, in your mysterious horrors, the happiness of one man.

"Atala offered but a feeble resistance: I was almost touching the moment of bliss, when all of a sudden an impetuous flash of lightning, followed by a burst of fire, cut a line through the thick darkness, filling the forest with sulphur and light, and breaking a tree at our feet. We fled. Oh, surprise! In the silence that followed, we heard the sound of a bell!" (Pp. 75-76)

In romantic fashion, Chateaubriand's raging elements and responsive forest are in sympathy with the lovers: the correspondence between the storm and the approach of "bliss" for Chactas is almost too perfect to be properly "artistic" and signals, instead of the willed construction of the literary artifact, a natural congruence between nature and extrasocial humanity. But with great economy Chateaubriand reinstitutes separation with the same movement that posits unity and imposes a natural check on natural impulses. The thunderclap, the lightning, the falling tree are implicit in the storm; the warning against the object of desire is implicit therefore in the very force of desire; the rupture between man and nature is inherent in their relation, in an unresolvable tension that also becomes a stability of man-in-nature and does not threaten the relation of power between him and the man-in-culture who writes him.

But for Chactas and Atala there is another element at play: the necessary excess of Christianity, whose signal, the bell, arises immediately after the tree falls, in the silence that follows naturally upon the violence of the thunderclap. The bell reminds us that Chateaubriand and his readers cannot imagine for his protagonists a freedom not constrained by the civilization that writes them. Atala is part of the dream of a civilization and is intended to be read within its system of values. The fury of the elements is therefore not sufficient to thwart the "natural" outcome of the passion beween her and Chactas; it needs the complement of the rescuing missionary's bell, which reintroduces the limits imposed by civilization identified with Christianity. If Chateaubriand and his public are to write and read savages as human, they must also keep them within culturally determined definitions of the human. At best, then, Chateaubriand offers a sleight-of-hand, the natural within the systems of civilization, like a magic rabbit in a top hat. 
Saved by Christian civilization from undisciplined indulgence in "natural" passion, Atala finally enters the exchange of histories which makes up the novel. Readers and characters find out that she has been vowed to lifelong virginity, that her passion may not seek the socially sanctioned and regulated outlet of a chaste marriage. Atala is the illegitimate daughter (by rape?) of an Indian "princess" (savage nobility characterized in terms of European political hierarchy) ${ }^{26}$ and a Spaniard. Converted to Christianity by a Franciscan monk, Atala's mother on her deathbed consecrates her daughter to a life without men, using the religion of the conqueror against one of the forms of his conquest and erecting her own barrier to exchange. With the mother's vow Chateaubriand turns a European prohibition against sexual contact into an American rejection of contact and, reassuringly, places the burden of denial on the other. Torn between love and loyalty, Atala poisons herself with her mother's potion and dies amid the consolations of Father Aubry and the groans of Chactas.

The savage groans and Christian consolations with which Chactas and Father Aubry react to the death of Atala reestablish the separation between European and American threatened during the stay in the forest; her death, meanwhile, confirms the interdiction against the lovers' "wedding." But Father Aubry frames the interdiction in completely European terms by transferring to the Americas a religious controversy between Jesuits and Franciscans and placing the cause of the ban not in the intrusion of the bell but in the unreasonable Franciscan sanction of an excessive vow. This explanation further determines the "reading" of the American tragedy in European terms by allowing Chateaubriand, the writer-politician, to intervene in an extratextual French political debate.

If the root of Atala's dilemma is sunk in European politics, its embodiment in the impossible choice between two virtues is the stuff of tragedy and inscribes her "savage" story in a high-culture literary series. Yet this inscription also marks her difference, since one of the terms of her dilemma is an alienating and exotic, rather than cathartic excess. The demands to which Atala cannot reconcile herself are those of a culture half alien to her whose worth she must acknowledge and to whose power she must bow because of her very virtues; loyalty and imperfect knowledge characterize her noble half savagery and force her to honor her mother's decision to accept Christianity as a revenge against Chris-

${ }^{26}$ Pocahontas is a "princess"; Oroonoko is an African "prince." 
tians. The impulses that conflict with these demands are permitted in the culture of her other half: as the "spouse" of Chactas condemned to death, she would have been obliged to yield to him; her partial yielding in the forest is never held against her in the text. Placed between two cultures she is potentially a mediating character; in effect, however, she exemplifies the impossibility of transition. Chateaubriand claims in the preface that his story is a tragedy, a form with no room for transition or compromise.

This reference to genre deflects attention from the fact that Atala's destruction arises not, as in tragedy, from the contradictions inherent in a single culture but from the conflict between contradictory elements in two cultures, each furnishing her with one of the weapons that kills her. Her mother's vow, with its misunderstanding of Christianity, affirms the positive value of a religion that commonly justified colonization and at the same time implies the inability of the colonized either to receive it in its perfection or to make a return of equal value. Her mother's poison, however, allows Atala to distance herself from Christianity by following a more ancient classical model of European virtue.

Though the different reactions to the death of Atala begin by affirming the incompatibility of culture-characteristic stances and reproduce the rupture between the aims of the lovers and those of the culture that writes them, Chateaubriand finally abuts on a rupture within the European position itself. Father Aubry's consolation, a traditional spiritual discourse of resignation and rejection of the world, modulates to a wholesale and emotional rejection of European civilization. "What would you think then," he asks the dying Atala, "if you had been witness to the ills of society, if, upon setting foot on the shores of Europe, your ears had been assaulted by the long cry of pain that rises from that old land?" (p. 103). The logic of his argument resides outside the text; Chateaubriand's discourse of the Americas is a discourse for Europe, to which America (whose acquiescence is adduced in the author's assertion of accuracy) is allowed as a spectator, like a child allowed to listen to the conversation of an adult dinner party. America is a laboratory for the examination of European problems, where one can isolate matters of fact and value. Because he assigns value to American characteristics, however, Chateaubriand can not only consolidate the discourse of Europe on America but also buttress that of America about itself. American authors use the elements he identifies as valuablethe immediacy of nature, the exemption from history, the purity and strength of emotions, the fiction of a new beginning-because these 
oppose and correct European characteristics and legitimate American difference. The result is a metonymic spread of positive value to other characteristics considered important in autochthonous literature though not relevant to the metropoles, such as the narrative form given to the subjugation of the Amerindian other in the formation of the American self. ${ }^{27}$

So far we have seen how Chateaubriand encodes the relation of an exotic America to a conquering Europe in a marriage plot that transposes to the personal level the possibility of combining cultures. In Atala and in René, as in Paul et Virginie, the marriage plot also presses into new service the then-common theme of incest and plays it against the more obvious one of exogamy, using religion as the operative difference. Because the psychological and the ideological do not usually meet in critical discourse, the relation of mutual implication between exogamy and incest in the literature of the exotic is not usually noted. In Chateaubriand that relation appears with unusual clarity and consistency. His interest in the incest motif has received critical attention, but its ideological dimension is generally submerged in speculation about the intense relationship between the young Chateaubriand and his sister, Lucille. ${ }^{28}$ In René the relationship between René and his sister, Amélie, conditions the hero's destructive interest in the Indian maiden Céluta, clearly opposing forbidden incest to impossible exogamy. But the relationship between Chactas and Atala, culturally distant from the author, is even more directly indicative of the thematic importance of the incest motif in the acculturation plot.

Balancing the anxiety of the encounter with otherness and the reassurance offered by the reencountered self, variations on exogamy as acculturation recur in most fictions by Chateaubriand. In Les martyrs

${ }^{27}$ This preoccupation appears both in Cooper's treatment of the origins and legitimacy of landownership and transmission from colonizers to the following generations and in the Brazilian Jose de Alencar's fascination with legends of place, where future generations of Brazilians can seek their national roots.

${ }^{28}$ The precise nature of Chateaubriand's relationship with Lucille has fascinated biographers; they agree that it was intense, exclusive (in the isolation of Combourg, where both spent their adolescence), and important for Chateaubriand's development as a writer. Judgments on the likelihood of "something" having happened between them vary according to the temperament of the biographer. Louis-Martin Chauffier heatedly denies Chateaubriand's "guilt" and especially Lucille's (Chateaubriand, pp. 39-40). Painter agrees, but reasons that in the absence of proof, we will never know for sure (pp. 64-66). Barbéris glances at the "erotic madness" of the "friendship with Lucille," without judging or elaborating (Chateaubriand: Une réaction, p. 25). André Maurois suggests that the intensity of the relationship depends precisely on the repression of its sexual component (René, pp. 33-36). 
he pairs Christian man and pagan (Roman) woman, and in Le dernier Abencérage, Christian woman and infidel (Muslim) man. ${ }^{29}$ In the American fictions the translation of the anxieties of acculturation and cultural replacement into the incest/miscegenation marriage plot receives a treatment that endures in the American literatures of nationality, where the marriage plot, with its companion the incest plot, can function as a multivalent metaphor for the complexities of acculturation. ${ }^{30}$ Within it, Atala's "savagery" is not simply ornamental, and her misguided Christianity is not accidental. She completes the series that goes from Chateaubriand's oriental protagonists through Céluta and Chactas to René and Father Aubry in increasing degrees of "Europeanism," erasing lines of absolute difference and tempting with the delights of a crisis of identity whose interest is intensified by the specter of incest. The contortions with which Chateaubriand introduces incest into Atala also indicate its importance for the construction of the exotic, for even if his preoccupation with incest is biographical, no biographical necessity would force him to develop it in an exotic setting. If, nevertheless, the incest motif is grounded intra-or intertextually-that is, if it derives from an internal logic of the acculturation motif which operates also in Paul et Virginie, especially in its stated preference of the more intense sibling love over a more demanding exogamy-then its presence in Atala is a further sign of the importance of exogamy as a grounding metaphor in fiction about the exotic and its relation to a model culture.

Chactas is the first to describe his lover as his sister, when she discloses that she is the daughter not of the Indian chief but of the same Lopez who, like a father, had sheltered and educated Chactas. This equation of the biological and the cultural becomes problematic in the writings of autochthonous American authors too, for it impedes the affirmation of a newly founded, independent cultural identity by demanding payment of a cultural debt to the former metropoles. In Atala the equation serves contradictory functions. As a morally positive value,

${ }^{29}$ Chauffier notes the pattern but connects it with the incest motif only by suggesting that in either case Chateaubriand took little trouble to invent new plots (p. 49).

${ }^{30}$ Eric J. Sundquist discusses the role of incest in Cooper's work at some length, though he links it not to the problems of acculturation in the New World but to a later phase in which a patrician class uses it as a method for preserving its privileged position against the pressures of Jeffersonian democracy (Home as Found, pp. 11-16). Doris Sommer, in classifying the literatures of nationality as "romance," also foregrounds the marriage motif, more optimistically than it is envisioned when coupled with incest, perhaps because she concentrates on those literatures' concerns with intranational differences. 
it proposes a cure for the cultural alienation that plagued the European consciousness by erasing the break between culture and nature, seen as the origin of alienation, the source of solitude, the abyss between self and other. As a negative value, it blocks the marriage plot and alleviates the anxiety of cultural otherness by preserving the self from dissolution into the other, proposing an end to alienation as dangerous as the alienation itself. For alienation can also function as an identifying characteristic of the self, threatened by the exogamous marriage plot, which raises the dangerous possibility of allaying alienation by changing the rules that govern, with the force of nature, the proper allocation of mates. The discourse of the exotic shows the marriage plot on the dangerous boundary between nature and culture, threatened by extrasocial desire immediately rejected as extranatural, as that which cannot be inscribed.

Structurally, the incest theme in Atala links Chactas and his interlocutor, René, and both with Chateaubriand himself as the exemplary European in America. Inasmuch as the love between Atala and Chactas remains unconsummated and ends tragically, however, like the marriage of René to Céluta, the New World becomes, as Barbéris observes, a site where marriage, the objective of the bourgeois novel, cannot occur (René de Chateaubriand, p. 107). And if marriage, as the seed and microcosm not only of the bourgeois novel but of any social group, cannot occur, the implication may be that the New World cannot be the site for the establishment of a new, hybrid, civilization. Though Barbéris values the impossibility of marriage positively, because through it the New World subverts bourgeois society, it can also be valued negatively, either as denying the possibility of sexual integration on which social integration depends (René de Chateaubriand, p. 109), or as denying the possibility of an alternative to that society.

The limitations of Atala as a discourse about the other show in plot, narrative focus, and characterization the necessarily paradoxical nature of a discourse by the other emergent as a self within the same linguistic and cultural context. As a discourse of the exotic, Atala both offers and denies true alternatives to dilemmas inherent in the dominating culture, brought into relief as it approaches the other; it also shows the naturalness with which evasion can be accepted as synthesis or, conversely, as a point of departure for an opposing discourse.

According to Jean-Pierre Richard, René's inadaptation, like the "ennui" with which he infects (or which he expresses for) a generation of 
European youth, is one of the ways in which Chateaubriand introduces "into the bosom of the American destiny ... the fault, the fatal principle of nonadequation" (Paysage de Chateaubriand, p. 37). But by its implied definition, this principle functions only in the juxtaposition of cultures and only from a European perspective. In the combination of morality and titillation offered in the story of Atala and Chactas, incest, as a sign of social inadaptation, complements exogamy and blocks the marriage of the protagonists just as it heightens the emotional charge of their encounter: "It was too much for our hearts, this brotherly friendship visited upon us and adding its-love to ours" (Atala, p. 75). But exoticism also legitimates passion and incest, by placing them at the origin of the civilization whose high morality promises a formula for adaptation and defines a proper distance from the virtuous prurience of the relationship between the lovers. As Father Aubry explains to Atala: "I will not speak to you of the marriages between the firstborn of men, of those ineffable unions in which the sister was the spouse of the brother, in which love and brotherly affection mingled in the same heart, and in which the purity of the one increased the delights of the other" (p. 104). The exotic neutralizes the culture-bearing function of the incest taboo, but the dangers of incest as well as of exogamy arise only through European intervention. They are imposed on America like Atala's cross and Chactas's enslavement, and these two in turn are defined as receptive vessels for a European definition of America which usurps their voices while confirming them as the only proper representatives of a new, American civilization.

The tragedy of Atala hinges on the double division between nature and culture, operated by the incest taboo and by Christianity. The appearance of the supplementary distinction is called forth by the ambiguous place of the Amerindian in the determination of the boundary between nature and culture. The savage, when noble, embodies the virtuality of culture and disturbs a system of differences between instinct, immediacy, iteration, on one hand, and thought, memory, history, on the other. Noble, he becomes the ancestor, associated with ancient Greeks and Romans and, like the ancients, subject to redemption by Christianity. Savage, he becomes the antagonist, subject to forceful domination by Christianity. Atala depends on both views. Chateaubriand's insistence on classifying Atala as a tragedy, like Henry Fielding's invention of the literary category "epic poem in prose" aims to derive respectability from the classics but also distances his characters 
and qualifies their virtue as surpassed by that of his modern readers. ${ }^{31}$ Out of a noble and ancient despair, Atala poisons herself to escape the conflict between duty to a vow and the desire of her noble heart. But like a savage, and unlike the tragic hero of classical French theater, she does not know all the rules that govern her field of potential action; she drinks the potion not because, like a hero, she rejects compromise but because, like a savage, she does not know it is possible. "What!" she exlaims, "was there a remedy! Could I have been relieved of my vows!" And Father Aubry comforts her: "Yes, my child," and tells her about the sorry state of Europe (p. 99).

Although Father Aubry's effect on the destiny of the lovers is negative-he blocks their embrace but not Atala's suicide-he is written as the most unambiguously positive character in the tale. Through him European cultural power reaches even into the deepest wilderness. It is not a virtual, metaphoric reach. Like the first missionaries he has set up a village in the middle of the forest and hurried its inhabitants out of "primitive" hunter-gatherer nomadism into the more "civilized" state of the peasantry. Benevolently, he presides over their young polis, still virtuous enough to generate, as in Rousseau's dream, the perfect society. But the good father modifies the Rousseauean model and replaces the consent of the governed, the contract that legitimates authority, with the absolute power of an alien, universalizing system of rules and values.

Blessing, marrying, baptizing, and burying, Father Aubry controls the points at which social organization sanctions and integrates the activities of individuals. But he also blesses "the rock, the tree, the fountain just as, in other times, and according to the book of the Christians, God blessed the uncultivated land, bestowing it upon Adam as his inheritance" (p. 90). This gesture assigns to the conqueror a divine right to the new paradise and places him at the origin of the world, of society, and of history.

But Father Aubry is not only the creator and the legislator; he is also the tutor, who, like his model in Rousseau's Emile-or like the state in the newly independent American nations-tries to build the good society on careful and illustrated instructions, parceling out rules and knowledge for his pupils' virtue and happiness. ${ }^{32} \mathrm{He}$ distributes land

${ }^{31}$ Chateaubriand points to the parallel in the Preface to Atala (p. 9), when he notes that, like Philoctète, his tale has only three characters, and within the text itself, when he introduces Chactas by comparing him to Oedipus and Ossian (p. 32).

${ }^{32}$ Recently there has been considerable critical interest in how the state controls socialization through education. See, for instance, Ross J. Pudaloff, "Education and the 
and crops to teach notions of property and "social economy," and to preserve "fraternal charity" (p. 90), but he has also "endeavored, in teaching them the road to salvation, to apprise them of the first arts of life, without, however, taking them too far along, and maintaining these honest people in that state of simplicity which brings happiness," because he "felt the superiority of this stable and busy life over the errant and idle life of the savage" (pp. 82, 91). His program combines criticism of the European fall from virtue with a rejection of the unmodified life of the savage and places all power in the hands of the European tutor. Father Aubry refuses to spell out for the governed the principles that govern them: "I have not given them any law: I have only taught them to love each other, to pray to God and to hope for a better life: all the laws in the world are contained in these" (p. 90). His benevolence is also his power; in his village exotic otherness provides a redemptive alternative to the sophisticated, historical European self, but only by being barred from becoming a covaluable equal. Father Aubry proposes to preserve his ideal society by removing it from history and withholding from it the knowledge of writing, which is the foundation of history as understood by Europe and which promotes the consciousness of the self and its place in the world-both seen to be at the root of European malaise. Father Aubry confirms history and writing as privileges of Europe, which has misused them, to be kept from a New World conceived as a preserve of virtue. Characteristically, Chateaubriand restores, in the relation of power between European and American, a relation of power between the church and public disturbed by the Reformation, the printing press, the Enlightenment, the Revolution and, at the limit, the discoveries that made Father Aubry's alternative society possible.

Father Aubry fails, however. The European imposition of history on "primitives" - the steps from nomadism to settlement, from hunting and gathering to agriculture, from idols to the true God-subjects the original inhabitants of the New World to European history. Father Aubry's ideal village is built, like Marie Antoinette's dairy, on the notion of a primitive simplicity that exists only as a relation not between myth and history but between two social groups of unequal power. The Indian village is destroyed, like the dairy, as the struggle for power erupts. In the Edenic Mississippi wilderness, roving tribes displaced by the

Constitution," and, for verification in the Brazilian case, Marisa Lajolo and Regina Zilberman, A leitura rarefeita. 
conquerors and caught up in alien disputes for their land, make war against each other, borne along on that current of history which Chateaubriand dreamt they should oppose.

And so we return to Chactas, who is only an admiring spectator of Father Aubry's village. Though an Indian like the missionary's wards, as Renés interlocutor he mediates between the two cultures, completely belonging to neither. Atala's death leaves him in an almost antagonistic relationship with Father Aubry and Christianity. "Perish the God who goes against nature," he cries, rolling on the ground and biting his own arms with savage fury, when Atala dies of virginity and poison (p. 96). But after enslavement gives him the opportunity to see secular European civilization, he can accept its spiritual offering and is competent to comfort René. It is an accommodation refused by another Chateaubriand pagan, Aben-Hamet, the hero of Le dernier Abencérage; the difference between them distinguishes the Amerindian otherness, conceived as an absence, from the Muslim one, conceived as a cultural opposition. Both are ineffective; neither hero wins his beloved; neither leaves the impress either of action or of posterity on European history.

Chactas is ineffective because Chateaubriand can see America only as a natural world to which the original inhabitants belong like the water buffaloes or the butterflies that adorn it without leaving their mark on it, without making history. Chateaubriand's savages differ from civilized people less in their closeness to nature than in their distance from history. Although René feels alienated because, unlike the Indians he meets, he does not carry the bones of his ancestors on his back, this connectedness he envies is structurally untranslatable for him (p. 123). The Indians' portable history shares the transitoriness of their nomadic life, out of which heroes such as Father Aubry must lead them. ${ }^{33}$ It is incomplete, since it does not produce the monuments that provide Chateaubriand with his bearings in time and space, determining the value of what he discovers and describes. ${ }^{34}$ Without such monuments

${ }^{33}$ It is interesting to compare this representation with that of the Jesuit relations discussed in Chapter 2. Chateaubriand does not mention anything like the permanent burial grounds to which the bones were taken eventually; the argument for greater piety of Amerindians forcibly confronted with mortality does not occur to him; though he presents the defense of Christianity as central to his literary endeavor, it is the argument about a secular civilization, for which history is not a given, that has his attention.

${ }^{34}$ See Michel Riffaterre, "Chateaubriand et le monument imaginaire." Hermine Riffaterre argues that the monuments can also be literary: Chateaubriand will often explain something he has in front of his eyes by reference to another landscape he has only read about but which carries the cultural weight of classical associations ("L'imagination livresque"). 
the American wilderness is free from the corruption of time but also inferior to those societies whose ancestors are safely weighed under the heavy, inscribed stones that anchor their descendants to the orderly flow of a historical process. Thus, while he longs for the integration with nature possible in the absence of history, Chateaubriand's hero, defined by a European historical sensibility that alone produces that longing, cannot receive what the exotic promises. Barbéris shows how this disjunction operates by reading Les Natchez allegorically, the Indian rebellion figuring a crisis in the reign of Louis XVI, contemporary with its setting, which in turn foreshadows another in postrevolutionary France contemporary with its writing (Chateaubriand, pp. 63-64). But these allegories do not clarify events by transposing them to a different level; they repeat events in ever-changing guises and despair of an exit.

This stress on problems of history may seem excessive, inasmuch as Atala is not ostensibly a historical novel but a love story to which the Natchez uprising is only peripheral. Yet Chateaubriand begins the prologue with history. "In days of yore," he writes, "France possessed, in North America, a vast empire which stretched from Labrador to the Floridas, and from the shores of the Atlantic to the most remote lakes of Upper Canada" (p. 27). The tale depends on European colonization; its moral conflict arises from a difference between two religious orders about jurisdiction over savage souls. One cannot blame Chateaubriand for deeming European politics a matter of life and death for Americans; one can, however, point out that insofar as Atala constitutes a model fiction of and about the Americas, it presents an autochthonous American fiction with a particularly clear statement of the problem of adapting a discourse made acceptable for its ideological charge to a use that must deflect that charge.

Chateaubriand knows that European history can always intrude upon the farther reaches of America. In Mémoires d'outre tombe he tells the end of his American voyage. He is a guest at an idyllic mill where fish jump in the brook, birds fly in the air; sitting by the fire, a cat on his knee, he feeds the hearth with scraps of old newspapers, alternately glancing at them and watching a squirrel frolic on the back of a large dog. Suddenly he reads that the Revolution has forced the king of France to flee. He has a vision of himself as a hero of Tasso's in a painting he admired in Naples (years after his American voyage): honor calls him back to aid the Bourbons (1:340). ${ }^{35}$ Whatever the real story-maybe

${ }^{35}$ In note 8 , on that page, the editor traces Chateaubriand's reference ("A sudden conversion took place in my spirit: Renaud saw the picture of his weakness in the 
only that his money was running out-Chateaubriand turns it into a parable about the difficulty of escaping European history, which exerts its pull even in the depth of the wilderness. But before it can be a story about the pull of history, it has to be a story about the desire to escape it. The escape is not toward the abstract, the ineffable, or the mystical but toward the exotic. The exotic does not exist in or for itself, however. It is there in relation to the familiar, to be consumed, reported, inscribed in the play of alternatives to the customary and the normal.

Finally, the exotic is there to be written. Chateaubriand brings home neither the map of the Northwest Passage nor an addition to French glory or territory but a sheaf of papers, which he carries around in war and into exile and credits with saving his life in battle (Atala, p. lxiii). That protective text constructs an exotic landscape integrated in the language of the more powerful consumer of exoticism. Its inscription of the wilderness teaches a generation of sensitive and solitary Europeans to rewrite their own mountains and valleys, grasses, birds and skies, and provides a generation of newly independent Americans with a language with which to write their difference as nature into civilization. We learn that yellow roses on islands floating in the Mississippi "rise like small pavilions"; vines and begonias climb the tallest trees, "forming a thousand grottoes, a thousand vaults, a thousand porticoes"; a tree on the opposite bank of the river is like "a joyous hostel ... an airy castle"; and as "a thousand sighs rose from the vaults and the corridors of that mobile building, never did any of the marvels of the ancient world come close to this monument of the wilderness" (Atala, pp. 28, 29, 64). Chactas speaks this last description; Chateaubriand enlists his semisavage voice, indistinguishable in tone, vocabulary, and reference from that of the narrator, assimilates it to a European discourse, and endows it with the universality of sensibility. The transposition of the narrator's language to the Indian protagonist, like the translation of plants into buildings, is not a slip but a consistent strategy, apparent also when Chactas transposes cultural value judgments and asserts that "drunkenness, which lasts a long time among the Savages, . . . is, for them, a kind of malady" (p. 62). With this strategy Chateaubriand separates Chactas from the "savages," familiarizes the strange,

mirror of honor in Armida's gardens; though I was not Tasso's hero, a similar mirror showed me a reflection of myself in the middle of the American bower") to a painting of that episode from Tasso which Chateaubriand admired on his trip to Italy in 1804: cultural artifacts color, even anachronistically, his view of American nature and of himself in it. 
and bestows value on American nature by translating it into European monuments. Thus, the savage other's consciousness of self is assimilated to the civilizing conqueror's, and the encounter with the other is saved from being an encounter with true otherness.

But familiar judgments and familiar architecture are not all that Chateaubriand superimposes on the wilderness. The same tree described as a castle and a hotel is also encoded as a product of European luxury manufacture: during the day a multitude of butterflies, insects, and birds surround the tree, attach themselves to the mosses hanging from it, and produce the effect of a "tapestry on white wool, where a European worker embroidered brilliantly colored insects and birds" (p. 64). The hand of the European worker legitimates the beauty of the American tree; moreover, translation of a translation, the description matches an actual Gobelins tapestry, based on drawings by travelers to the Americas. ${ }^{36}$ This inscription of the American landscape tames the wilderness as it claims to describe it. It ascribes value to the landscape by inserting it into a tradition of European high culture which has already assimilated and forgotten an earlier influx of the exotic, and it ensures Chateaubriand's power to control otherness within a familiar language. It peoples the forest with an Indian youth who is just like a young Greek spirit, a romping "genie of Spring"; with another young Indian sitting upon a rock like a classical marble statue; with the Amerindian version of the myth of Orpheus; or with the Indian lover who completes the recuperation of the European past in the American wilderness by singing to his beloved a "natural" echo of the Song of Songs: "Her breasts are like two spotless fawns, born on the same day from the same mother" (Atala, p. 47, 56, 48).

In this context, the most daring figure of inscription becomes almost commonplace. Like a lover at a picnic, defacing trees with hearts and initials, Father Aubry carves into the trunks of centenary oaks outside his cavern the Song of Songs and the epic poems of Homer (Atala,

\footnotetext{
${ }^{36}$ The Museu de Arte de São Paulo owns a tapestry titled Indian Hunter, based on designs by Albert Eckout, transported to paper boards by François Desportes, and part of a series called Nouvelles Indes, the originals of which were sent by Maurice of Nassau as a gift to Louis XIV of France in 1687, and transferred to the Gobelins workshops in the same year; there they were reproduced until 1730, when they wore out. The tapestry at São Paulo shows a pair of trees, composites of palm, cactus, and deciduous forms, carrying, and surrounded by, an encyclopedia of the flora and fauna of the Americas (Carlos Lemos et al., The Art of Brazil, p. 45).
} 
p. 84) ${ }^{37}$ There Chateaubriand operates a direct transformation of nature into culture which leaves intact the appearance and the essence of both by assimilating the natural to the early and the other to the ancestor, translating the strange language of otherness into writing and history. As directly as that, Chateaubriand transforms the New World into an element in the discourse of the Old.

In time Chateaubriand's encoding of the New World assumed the position of model and adversary for American literatures of national consciousness. He brought the New World into the mainstream of literary discourse in the Old and invested it with contemporary significance. He did so, however, by transforming it into pure raw material to be used in accordance with the syntax of a culture from which the new literatures were striving to differentiate themselves. Their task, then, was to define the autochthonous and affirm its value while rescuing it from the classification of otherness on which identity and value had till then depended. Cultural independence demanded the affirmation of identity without putting the ascription of value into jeopardy, the rescue of the exotic from servitude to the system that defined it as exotic, and its transformation into the domestic without sacrifice of its claim to value. It demanded the recovery of authority from an alien inscription, a daring, critical redefinition of exotic otherness as an element in the definition of the self.

Chateaubriand wrote America for Europe, inscribed Europe on the New World, created a wilderness that, though unable to satisfy it, provided a space commensurate with European desire. Like the voyagers in whose footsteps he wished to walk, he gave the European imagination a geography of escape and transformation. He did it by investing the wilderness-that place without history, without writing, without the

\footnotetext{
${ }^{37}$ Though writing the Iliad on trees might seem an overstatement of inscription, a passage in Chateaubriand's later assessment of the contemporary state of the United States shows that he not only saw the process as inevitable, engaged in by Americans themselves in tineir claim for legitimacy, but also, at least if performed by Americans, as faintly ridiculous, certainly incongruous: "There is, among the Muscogulges, the Seminoles, the Chickasaws, a city of Athens, one of Marathon, another of Carthage, another of Memphis, another of Sparta, another of Florence. . . . In Kentucky one finds a Versailles" (Memoires 1:342) The sense of estrangement aroused by these familiar names in unfamiliar settings is present throughout even the laudatory account of the material progress of the United States, the improvements in transportation, and the increase in population, and finally turns to ill-concealed contempt when Chateaubriand considers the literary scene and the works of such as Charles Brockden Brown and James Fenimore Cooper ("Les lettres aux Etats Unis," Memoires, 1:344-50).
} 
rules that mark familiar boundaries of culture-with a positive value as an otherness from which Europe could reassume its own history, its own place, its own self. That reassumption, however, imposed on the wilderness, as signs of value, those very boundaries it had existed to deny, subjecting it to European history, inscribing it with European writing, subordinating its social organization to the origins of Europe's. Nevertheless, the new literature of the Americas was able to use the positive evaluation of its defining characteristics as a pivot on which to give the wilderness another spin, to assign it an autochthonous value, and to translate it from an otherness to a mediating self, readable on either shore of the Atlantic.

The nineteenth-century literatures of nationality developed a variety of strategies to recover the wilderness for the definition of a national cultural consciousness. They assimilated European origins to New World histories, affirmed the value of original New World cultures on their own terms, denied the importance of these cultures, and attempted to incorporate New World elements into a definition of national character that at the same time valued them and transformed them. The categories of history, of marriage, of the boundaries between nature and culture have been constants in the development of such national or cultural discourse. Barbéris claims that like Balzac and Beyle, Chateaubriand "taught us to read the modern world" (Chateaubriand, p. 352). To participate in this discourse, New World writers had to write against this reading and, therefore, to incorporate it. 